Author's Accepted Manuscript

\title{
1 Elevated nutrient concentrations in headwaters affected by drained peatland
}

2

3 Hannu Marttila* ${ }^{a *}$,Satu-Maaria Karjalainen ${ }^{b}$, Minna Kuoppala ${ }^{b}$, Mika L. Nieminen ${ }^{c}$, Anna-

4 Kaisa Ronkanen ${ }^{\mathrm{a}}$, Björn Klöve ${ }^{\mathrm{a}}$, Seppo Hellsten ${ }^{\mathrm{b}}$

5

$6{ }^{a}$ Water Resources and Environmental Engineering Research Unit, PO Box 4300, 90014

7 University of Oulu, Finland; hannu.marttila@oulu.fi, anna-kaisa.ronkanen@oulu.fi,

8 bjorn.klove@oulu.fi

9 binnish Environment Institute, Freshwater Centre, PO Box 413, 90014 Oulu, Finland; satu-

10 maaria.karjalainen@environment.fi,minna.kuoppala@environment.fi,

11 seppo.hellsten@environment.fi

12 'University of Jyväskylä, Department of Biological and Environmental Science, PO Box 35,

13 FI-40014 University of Jyväskylä, Finland; mika.nieminen@ gmail.com

14

*Corresponding author at: Water Resources and Environmental Engineering Research Unit, PO

Box 4300, 90014 University of Oulu, Finland. Telephone: +358 29448 4393, E-mail address:

hannu.marttila@oulu.fi (H.Marttila)

18

19

Keywords: peatland, drainage, water quality, headwaters, isotopes

20

21

\section{Highlights}

- Water chemistry, isotopes and hydrology in 62 boreal headwater catchments were studied

24 - Elevated nutrient concentrations were observed at drained peatland

25 - Current water protection methods are insufficient to trap all loads from drained peatland 


\section{Author's Accepted Manuscript}

\section{Abstract}

28 Nutrient export from drained peatland has significant impacts on aquatic environments in Nordic catchments. Spatial information on variations in nutrient concentrations across different landscapes and land uses is needed to design measures for achieving the good ecological status of the EU Water Framework Directive. In this study we determined background concentrations in natural peatland-dominated streams and examined effects of peatland use practices on water quality in headwater catchments. We quantified sources for different elements by joint analysis of water chemistry, isotopes, and hydrology for 62 small catchments in North Ostrobothnia, Finland. Concentrations of nutrients and suspended solids were relatively high in catchments containing drained peatland. In particular, dissolved nitrogen and phosphorus concentrations were elevated during baseflow conditions when flow likely originated from deeper soil layers. Total concentrations of nutrients, suspended solids, and loss on ignition also showed elevated values, and changes in the ratio of dissolved and particulate forms, especially the $\mathrm{C} / \mathrm{N}$ ratio, were observed. Past drainage had a stronger effect on organic matter and nutrients concentrations than local hydroclimate conditions. These results strongly indicate that current water protection methods are not sufficient to capture all seasonal variations in nutrient and suspended solid loads from drained peatland. Thus, more effort and actions are needed for water

44 protection in such areas.

\section{Introduction}

47 Increased demand for biomass in a circular bio-based economy can cause drastic changes in land use patterns and intensities. This adds a new and unknown pressure to climate change, which is already altering the hydrological cycle in boreal regions (Prowse et al. 2015). In highlatitude catchments, peatlands are already heavily exploited and this is predicted to intensify in

51 the near future (Christensen et al. 2007). This poses challenges to meeting or maintaining the 


\section{Author's Accepted Manuscript}

52 EU Water Framework Directive's good ecological status objective in headwaters and larger

53 watercourses.

54 The Nordic countries have a strong tradition of managing peatland, with around 15 million ha of paludified mineral soil and peatland being drained for forestry in the temperate and boreal regions (Paavilainen and Päivänen 1995). This has caused changes to terrestrial and aquatic

57 environments, since disturbance of soil, vegetation, and hydrological conditions results in

58 leaching and transport of various substances (for review, see Nieminen et al. 2018a). Identified

59 threats are increased erosion, water pollution, eutrophication, brownification, and biodiversity loss, especially in headwater catchments (Vuorenmaa et al. 2006, Rantakari et al. 2010, Räike

61

62

63

64 performed combined analyses of water chemistry, stable isotopes in water, and local hydrology. et al. 2012, Rääpysjärvi et al. 2016).

Although different peatland use practices such as forestry, agriculture, and peat extraction and their impacts on water pollution have been researched for several decades (e.g. Heikkinen 1990), there is a lack of spatially distributed water quality information for peatland-dominated headwater areas. Recent findings also suggest that old drainage areas contribute strongly to 'background' pollutant loading, due to increased decomposition of drained peat layers (Nieminen et al. 2017). Therefore, more information is needed about the variations in concentrations and dominant processes affecting water quality of headwaters in active or abandoned drained peatland areas. Peatland drainage is known to increase phosphorus, nitrogen, and suspended solids loads, but many previous studies have focused on drained areas and have overlooked the effect of drainage on headwater streams.

The aims of this study were thus (i) to obtain background concentration information for natural peatland-dominated streams; and (ii) to study the effects of drainage for peatland forestry and peat extraction practices on water quality in boreal headwaters. To this end, we The hypothesis tested was that concentrations of various elements are elevated in headwater 


\section{Author's Accepted Manuscript}

77 streams draining peatland-dominated catchments and that this is linked to land use practices 78 and hydrological flow paths.

79

80

\section{Methods}

81

\subsection{Study sites}

82 We selected a total of 62 headwater streams from peatland-dominated catchments for water

83 quality and sediment sampling (Figure 1, Table 1). These sites represent three different land uses, categorized as: near pristine, peatland forestry, and peat extraction. In selection of sites, particular attention was paid to obtaining good spatial coverage, including different land use types, and ensuring representation for each category (i.e., only one land use upstream from sampling sites). For peat extraction sites, the latter was not always possible due to surrounding peatland forestry areas. In peatland forestry areas, we selected sites older and younger than five years and sites with thin and thick peat layers.

We used $10 \mathrm{~m} \quad \mathrm{x} \quad 10 \mathrm{~m}$ digital elevation model (DEM, Paituli-database, https://avaa.tdata.fi/web/paituli) for estimating catchment boundaries, which were further edited using maps, aerial photos, and field surveys. Historical land use information was obtained from land owners, peat extraction companies, forestry associations, and a state-owned

94 forest enterprise (Metsähallitus). CORINE Land Cover 2006 (25 m x $25 \mathrm{~m})$ was used to calculate land use, while drainage intensity was calculated using data from the National Land Survey (Paituli-database) by dividing peatland in the dataset into near pristine, drained, and

97 peat extraction types. New peat extraction areas were digitized from aerial photos. Other land 98 types in the study catchment were categorized as unclassified and were mainly mineral soils, 99 but also a few lakes and ponds. Catchment-specific daily precipitation and temperature data were obtained from $10 \mathrm{~km}$ x $10 \mathrm{~km}$ interpolated grid produced by the Finnish Meteorological Institute (Paituli-database). 


\section{Author's Accepted Manuscript}

102

103

104

105

106

107

108

109

110

111

112

113

114

115

116

117

118

119

120

121

122

123

124

125

126

\subsection{Water sampling}

All sites were sampled 2-4 times during the frost and ice-free period (May-September) in 2012 and 2013 by taking standard grab water samples. These samples were analyzed for total phosphorus $\left(\mathrm{P}_{\text {tot }}\right)$, dissolved total phosphorus (dissolved $\left.\mathrm{P}_{\text {tot }}\right)$, phosphate $\left(\mathrm{PO}_{4}-\mathrm{P}\right)$, total nitrogen $\left(\mathrm{N}_{\text {tot }}\right)$, ammonium $\left(\mathrm{NH}_{4}-\mathrm{N}\right)$, nitrate-nitrite $\left(\mathrm{NO}_{2+3}-\mathrm{N}\right)$, and silica $\left(\mathrm{SiO}_{2}\right)$. Organic carbon content was measured by analyzing chemical oxygen demand (COD $\left.{ }_{\mathrm{Mn}}\right)$, total organic carbon (TOC), and dissolved carbon (DOC). Aluminum (Al), total iron (Fe), and dissolved iron (dissolved $\mathrm{Fe}$ ) content were also analyzed. Suspended solids (SS) content was analyzed using two different filters, Whatman GF/C $\left(1.2 \mu \mathrm{m}, \mathrm{SS}_{1.2}\right)$ and Whatman Nuclepore $\left(0.4 \mu \mathrm{m}, \mathrm{SS}_{0.4}\right)$. Loss-onignition (LOI) was analyzed using the GF/C filters. All analyses were conducted by an accredited laboratory, using standard methods for $\mathrm{P}_{\text {tot }}$ and dissolved $\mathrm{P}_{\text {tot }}$ (SFS-EN ISO 156811:2005), $\mathrm{N}_{\text {tot }}\left(\mathrm{SFS}-\mathrm{EN}\right.$ ISO 11905-1: 1998), DOC (SFS-EN 1484: 1997), $\mathrm{NH}_{4}-\mathrm{N}$ (SFS 3032:1976), $\mathrm{NO}_{2+3}-\mathrm{N}$ (SFS-EN ISO 13395:1997), $\mathrm{SiO}$ (SFS-EN ISO 16264:2004), COD ${ }_{\mathrm{Mn}}$ (SFS 3036:1981), TOC (SFS-EN 1484:1997), DOC (SFS-EN 1484:1997), Al (SFS-EN ISO 11885:2009, modified), Fe and dissolved Fe (SFS-EN ISO 11885:2009, modified), SS $_{1.2}$ (SFS SFS-EN 872:2005), SS $_{0.4}$ (SFS SFS-EN 872:2005, modified), and LOI (SFS SFS 3008:1990). During the sampling campaigns, water samples were also analyzed for $\mathrm{pH}$, temperature, and electrical conductivity (EC) in the field, using a WTW Multi 350i field meter. Prior to laboratory analyses, samples were stored in darkness at $+4{ }^{\circ} \mathrm{C}$ and analyzed as soon as possible. All samples for dissolved element measurements were filtered through $0.4 \mu \mathrm{m}$ filters within 24 hours of sampling, before analysis.

Stable isotopes of water $\left(\delta^{18} \mathrm{O}, \delta^{2} \mathrm{H}\right)$ are often used as tracers for studying the hydrological cycle. In this study, we determined the isotope ratios ${ }^{2} \mathrm{H} /{ }^{1} \mathrm{H}$ and ${ }^{18} \mathrm{O} /{ }^{16} \mathrm{O}$ by cavity ring-down spectroscopy with a Picarro L2120-i isotopic water analyzer. We expressed the isotope ratios in $\delta$ notation relative to Vienna Standard Mean Ocean Water (VSMOW) with precision for $\delta^{18} \mathrm{O}$ 


\section{Author's Accepted Manuscript}

127

128

129

130

131

132

133

134

135

136

137

138

139

140

141

142

143

144

145

146

147

and $\delta^{2} \mathrm{H}$ values of $\pm 0.1 \%$ ond $\pm 1.0 \%$, respectively. The samples were stored in cold $\left(+4^{\circ} \mathrm{C}\right)$, dark conditions prior to analysis.

We used stable isotopes and $\mathrm{SiO}_{2}$ as a proxy to separate summer precipitation and deeper soils/groundwater. Both methods have been widely used (Isokangas et al. 2017, Marttila et al. 2018), and provide natural tracers to separate different components in the hydrological cycle. For the stable isotopes of water, we determined local regional volume-weighted isotope value for summer precipitation $\left(\sim-10 \%\right.$ o for $\left.\delta^{18} \mathrm{O}\right)$ from precipitation measurements in the region (Isokangas et al. 2017). We used this boundary to separate summer precipitation from baseflowdominated flows at the study sites, with values higher than $-10 \% \circ \delta^{18} \mathrm{O}$ classified as summer precipitation-dominated flow conditions. We used $\mathrm{SiO}_{2}$ as a proxy for groundwater proportion in the flow. High $\mathrm{SiO}_{2}$ concentration indicates longer retention time in local groundwater (Isokangas et al. 2017), and therefore samples with high $\mathrm{SiO}_{2}$ values were classified as groundwater-dominated.

\subsection{Analytical methods}

The water quality parameters were aggregated based on land use category in order to understand the general patterns and behavior in the data. Pearson's correlation coefficient (r) was used to study the relationship between water quality parameters, land use, and antecedent conditions. The antecedent conditions considered were sampling day precipitation and temperature, and sum of precipitation and mean air temperature on the sampling day and in the previous 7-day and 30-day periods.

We explored the main patterns of variation in water quality parameters between all sites using principal component analysis (PCA). Prior to running the PCA analysis, we standardized the end products to have zero mean and unit variance on the covariance matrix. The final number of principal components (PCs) was determined using the broken-stick model (Jackson 


\section{Author's Accepted Manuscript}

152

153

154

155

156

157

158

159

160

161

162

163

164

165

166

167

168

169

170

171

172

173

174

175

1993), in which eigenvalues from a PCA are compared with the broken-stick distribution. Since each eigenvalue of a PCA represents a measure of a component's variance, a component was retained if its eigenvalue was larger than the value given by the broken-stick model.

We used multivariate clustering methods to generate groups with maximum similarity in three water quality groups formed in PCA analysis: suspended solids, nutrients, and carbon. Ward's hierarchical clustering (Legendre and Legendre 2012) was used for standardized water quality data and the final number of clusters was based on manual truncation of the dendrogram. The results from clustering were then utilized in a Random Forest (RF) (Breiman 2001) model in order to assess the environmental factors which best explained the clustering. As explanatory variables in RF, we used mean air temperature and sum of precipitation during the sampling day and in the 7-day and 30-day periods prior to sampling, land use, and oxygen isotope $\left(\delta^{18} \mathrm{O}\right)$. Random Forest models make no assumptions about the type of relationship (linear or nonlinear) between the predictor and response variables. We used the R-program implementation of RF to build the RF models (Liaw and Wiener 2002). Moreover, RF models integrate the combined output of many decision tree models (here 5000, i.e., the random forest), each using a different bootstrap sample from the original data. The predictions of the final RF model are an average of the predictions of the forest. For the forest, each tree is tested on samples not used in building the tree, providing an out-of-bag (OOB) estimate of the model error. The selection of the final RF model was based on visual examination of the variable importance plots (Cutler et al. 2007).

We used mean decrease in accuracy as the primary criterion of model fit. Higher values indicate variables that are more important for the classification.

\section{Results}

\subsection{Water quality in streams at sites under different peatland uses}




\section{Author's Accepted Manuscript}

176

177

178

179

180

181

182

183

184

185

186

187

188

189

190

191

192

193

194

195

196

197

198

199

In general, stream water quality in catchments containing drained peatland clearly differed from that at near pristine sites, especially as regards nutrient concentrations (Table 2, Figure 2). The measured median $\mathrm{P}_{\text {tot }}$ and $\mathrm{PO}_{4}-\mathrm{P}$ concentrations at peat extraction sites $\left(\mathrm{P}_{\text {tot }} 64 \mu \mathrm{g} \mathrm{1^{-1 }} ; \mathrm{PO}_{4}-\mathrm{P} 35\right.$ $\left.\mu \mathrm{g} \mathrm{l}^{-1}\right)$ and peatland forestry sites $\left(\mathrm{P}_{\text {tot }} 43 \mu \mathrm{g} \mathrm{l}^{-1}\right.$; $\left.\mathrm{PO}_{4}-\mathrm{P} 19 \mu \mathrm{g} \mathrm{l}^{-1}\right)$ were 3.5-fold and 2.5-fold higher, respectively, than those at near pristine sites $\left(\mathrm{P}_{\text {tot }} 18 \mu \mathrm{g} \mathrm{l}^{-1} ; \mathrm{PO}_{4}-\mathrm{P} 6 \mu \mathrm{g}^{-1}\right)$. The $\mathrm{N}_{\text {tot }}$, $\mathrm{NH}_{4}-\mathrm{N}$, and $\mathrm{NO}_{2+3}-\mathrm{N}$ values were 1.8-, 26-, and 15-fold higher, respectively, at peat extraction sites $\left(\mathrm{N}_{\text {tot }} 855 \mu \mathrm{g} \mathrm{l}^{-1} ; \mathrm{NH}_{4}-\mathrm{N} 79 \mu \mathrm{g}^{-1} ; \mathrm{NO}_{2+3}-\mathrm{N} 46 \mu \mathrm{g}^{-1}\right)$ and 1.4-, 4.3-, and 4.3-fold higher, respectively, at peatland forestry sites $\left(\mathrm{N}_{\text {tot }} 712 \mu \mathrm{gl}^{-1} ; \mathrm{NH}_{4}-\mathrm{N} 13 \mu \mathrm{g} \mathrm{l}^{-1} ; \mathrm{NO}_{2+3}-\mathrm{N} 13 \mu \mathrm{g}^{-1}\right)$ than at near pristine sites $\left(\mathrm{N}_{\text {tot }} 485 \mu \mathrm{g} \mathrm{l}^{-1} ; \mathrm{NH}_{4}-\mathrm{N} 3 \mu \mathrm{g} \mathrm{l}^{-1}\right.$; $\left.\mathrm{NO}_{2+3}-\mathrm{N} 3 \mu \mathrm{g} \mathrm{l}^{-1}\right)$. The TOC, DOC, COD $\mathrm{Mn}$, and Fe concentrations were at rather similar levels for all three land use categories (Table 2). Median aluminum concentration were 2.3- and 2.4-fold higher at peat extraction $\left(280 \mu \mathrm{g} \mathrm{l}^{-1}\right)$ and peatland forestry $\left(295 \mu \mathrm{g} \mathrm{l}^{-1}\right)$ sites than at near pristine sites $\left(124 \mu \mathrm{g}^{-1}\right)$. The lowest $\mathrm{pH}$ levels were recorded at near pristine sites, while peatland drainage tended to increase $\mathrm{pH}$ levels. The typical range of $\mathrm{pH}$ in minerotrophic peatland is 4.5 to 7.5 , but it is usually less than four in ombrotrophic peatland (Laine and Vasander 1996). In addition to peatland type, drainage also affects $\mathrm{pH}$ in peatland since higher $\mathrm{pH}$ has been observed in forestry drained peatland than in pristine mires (Paavilainen and Päivänen 1995; Haapalehto et al. 2014).However, the lowest single values (below 4) in $\mathrm{pH}$ were measured in streams after peat extraction, most probably because of acid sulfate soils in the area.

Drained peatland area and peat extraction area as a percentage of catchment area showed statistically significant positive correlations with $\mathrm{P}_{\text {tot }}, \mathrm{N}_{\text {tot }}, \mathrm{NH}_{4}-\mathrm{N}, \mathrm{NO}_{2+3}-\mathrm{N}$, and suspended solids (Figure 3). Drained peatland area was also positively correlated with TOC and DOC. In contrast, undrained peatland area showed negative correlations with these elements. Furthermore, drained peatland area was positively correlated with $\mathrm{Fe}$ and $\mathrm{Al}$ concentrations. 
The filter size used for SS analysis strongly affected the measured concentrations. On

201

202

203

204

205

206

207

208

209

210

211

212

213

214

215

216

217

218

219

220

221

222

223

224

average, the $0.4 \mu \mathrm{m}$ Nuclepore filter resulted $8.8 \mathrm{mg} \mathrm{l}^{-1}$ higher values than the $1.2 \mu \mathrm{m} \mathrm{GF/C}$ filter. The average difference was same for all peatland uses (U-test, $\mathrm{p}<0.05)$. SS concentrations at peat extraction sites (median $16.5 \mathrm{mg} \mathrm{l}^{-1}$ ) were slightly higher than at peatland forestry (15 $\mathrm{mg} \mathrm{l}^{-1}$ ) or near pristine sites (10.6 $\mathrm{mg} \mathrm{l}^{-1}$, Table 2). Proportion of organic matter (LOI) increased, whereas $\mathrm{C} / \mathrm{N}$-ratio from particulates and dissolved substances decreased, with peatland land use. There was a strong correlation between $\mathrm{SS}_{0.4}$ and $\mathrm{Fe}(\mathrm{r}=0.677, \mathrm{p}=0.000)$ and 30-day mean temperature before sampling (Figures 3 and 4).

\subsection{Impact of hydrology and temperature on water quality}

Weather conditions during the frost-free season did not have a major effect on nutrient concentrations in the studied streams. Only $\mathrm{NO}_{2+3}-\mathrm{N}$ showed negative correlations with air and water temperature (Figure 3). Conversely, suspended solids, organic matter (TOC, DOC, COD, LOI), and Fe concentrations showed positive correlations with air temperature before sampling (Figure 4), although with considerable variation. Stable isotopes of water $\left(\delta^{18} \mathrm{O}, \delta^{2} \mathrm{H}\right)$ and silica $\left(\mathrm{SiO}_{2}\right)$ were negatively correlated with dissolved nutrients $\left(\mathrm{PO}_{4}-\mathrm{N}, \mathrm{NH}_{4}-\mathrm{N}, \mathrm{NO}_{2+3}-\mathrm{N}\right)$ (Figure $3)$.

The highest concentrations of inorganic nutrients co-occurred with low $\delta^{18} \mathrm{O}$ and high $\mathrm{SiO}_{2}$, indicating presence of groundwater or leaching of inorganic fractions of nutrients from deeper soil water (Figure 5). A rather clear boundary was observed with summer precipitation value in $\delta^{18} \mathrm{O}\left(\sim-10 \%\right.$ in the North Ostrobothnia region) and $10 \mathrm{mg} \mathrm{l}^{-1} \mathrm{SiO}_{2}$ concentration. At near pristine sites, DOC and $\delta^{18} \mathrm{O}$ showed the most clearly increasing patterns, demonstrating higher DOC concentrations resulting from summer precipitation, which differs isotopically from deeper soil water and groundwater (Eskelinen et al. 2016). At peat extraction and peatland forestry sites the pattern was not as obvious, indicating high DOC values coming from deeper 


\section{Author's Accepted Manuscript}

225

226

227

228

229

230

231

232

233

234

235

236

237

238

239

240

241

242

243

244

245

246

247

248

249

soil water. In contrast, DOC concentrations decreased strongly $(r=-0.30, p=0.0035)$ with higher proportion of groundwater (higher $\mathrm{SiO}_{2}$ concentration). Both total and dissolved $\mathrm{Fe}$ showed a positive correlation with $\mathrm{SiO}_{2}(\mathrm{r}=0.32, \mathrm{p}=0.0013)$ (Figures 3 and 5), indicating that hydrological conditions and groundwater outflow in a catchment affect Fe concentrations. Patterns linking Fe and land use were not observed.

In the PCA analysis, four principal components (PCs) were observed and named suspended solids, nutrients, and carbon (see Appendix Figure A1 and Table A1). Together, these explained $80 \%$ of the variance in concentrations at the study sites. Groups formed in the PCA were used in the RF analysis. The most important variables in the preliminary RF model, including all predictor variables, showed some differences between the land use categories (Figure 6). For suspended solids concentration, the most important variables were 7-day mean temperature, 30-day mean temperature, other land use (not peatlands), peat extraction, 7-day precipitation sum, and stable isotope of oxygen. For nutrient concentrations, important variables were undrained peatland, drained peatland, peat extraction, other land use, and stable isotope of oxygen. For carbon, drained peatland, other land use, and undrained peatland were important variables. The final best models suggested that the classification accuracy was $46 \%$, $74 \%$, and $58 \%$ for suspended solids, nutrients, and carbon, respectively.

\section{Discussion}

\subsection{Elevated nutrient concentration in headwaters affected by peatland drainage}

In this study, elevated concentrations, especially of nitrogen and phosphorus, were observed in headwater streams in catchments where peat extraction and peatland forestry were the main land uses. At peatland forestry sites, the $\mathrm{N}_{\text {tot }}$ concentrations were in same range as reported by Nieminen et al. (2017), but the $\mathrm{P}_{\text {tot }}$ concentrations were higher. There was large variation in nitrogen and phosphorus concentrations, but in general rather high concentrations were 


\section{Author's Accepted Manuscript}

250

251

252

253

254

255

256

257

258

259

260

261

262

263

264

265

266

267

268

269

270

271

272

273

274

observed in headwaters in catchments affected by peatland forestry and peat extraction land uses. Near pristine sites showed similar concentrations to those reported previously for natural headwaters (Mattson et al. 2003, Nieminen et al. 2017).

Recent evidence shows that peatland drainage leads to increased leaching of nutrients over time (Nieminen et al. 2017). In this study, we lacked sufficient metadata on the time of initial drainage to peatland forestry or peat extraction sites to confirm this. However, our tracer results (stable water isotopes and silica) strongly indicated leaching of high concentrations of dissolved $\mathrm{NH}_{4}-\mathrm{N}, \mathrm{NO}_{2+3}-\mathrm{N}$, and $\mathrm{PO}_{4}-\mathrm{P}$ from local shallow groundwater or deeper pore water sources in areas affected by drainage. Using local isotope values for summer precipitation and water samples, we were able to roughly differentiate the main runoff sources during the sampling period (Figure 5). The results clearly showed that the highest concentrations of dissolved nutrients occurred during baseflow $\left(\delta^{18} \mathrm{O}\right.$ lower than $-10 \%$ and/or $\mathrm{SiO}_{2}$ values higher than $10 \mathrm{mg} \mathrm{l}^{-1}$ ) when the local groundwater/soil water source dominated runoff generation.

Streams draining peat extraction areas in particular had high $\mathrm{NH}_{4}-\mathrm{N}$ concentrations, indicating that the load originates from active surface peat layers in the extraction areas as a consequence of decomposition of peat layers due to intensive drainage (Svahnbäck 2007, Tuukkanen et al. 2017). Ammonium has particularly detrimental effects on water bodies, as it consumes oxygen and is directly available for algae and vegetation. Nitrate concentrations were rather high for both land use types, indicating longer pathways for nitrogen from drained peatland areas. Increasing nitrogen loads from drained areas are especially problematic for watercourses, since boreal streams draining peatland naturally contain low concentrations of dissolved mineral nitrogen (Sponseller et al. 2017), as our results confirm. Similarly, in addition to dissolved nitrogen concentrations, elevated $\mathrm{PO}_{4}-\mathrm{P}$ concentrations were recorded in shallow groundwater samples. Leaching of $\mathrm{NH}_{-4}-\mathrm{N}, \mathrm{NO}_{2+3}-\mathrm{N}$, and $\mathrm{PO}_{4}-\mathrm{P}$ from deeper peat layers in 'old water' has been documented in many previous studies conducted inside drained boreal peatland areas 


\section{Author's Accepted Manuscript}

275

276

277

278

279

280

281

282

283

284

285

286

287

288

289

290

291

292

293

294

295

296

297

298

299

(Eskelinen et al. 2016). However, our results highlight the importance of these processes also for concentrations in natural headwater catchments. Overall, there were rather large variations in nutrient concentrations between sampling periods and sites, demonstrating the highly variable nature of pollutant loads from drained peatland areas.

Interestingly, organic carbon concentration (TOC and DOC) and COD values did not differentiate between the pristine sites or between peatland uses. Instead, drained peatland percentage of the catchment showed a significant positive correlation with organic matter concentration. Part of this correlation seemed to depend on the quality of organic matter and $\mathrm{C} / \mathrm{N}$ ratio, which significantly decreased in drained areas (Fig. 2). This demonstrates that even when no effects on organic carbon concentrations were observed, drainage can modify the quality of organic matter in runoff waters. In previous studies, peatland drainage has been found to change the molecular composition of DOC (Huotari et al. 2013; Berggren \& de Giorgio 2015), thus modifying e.g., food web structures. Thus, drainage may not only change the concentrations of transported organic matter in stream water, but also the quality.

Leaching of nutrients and organic carbon is typically linked to changes in seasonal weather conditions (Lepistö et al. 2014; Finstad et al. 2016) or land use activities (Meyer-Jacob et al. 2015). Changing seasonal soil moisture conditions and redox conditions in particular are linked to increasing trends in DOC and Fe in boreal regions (Sarkkola et al. 2013). This has been linked with an increased risk of nutrient leaching from land use activities (Tattari et al. 2017), while increased DOC leaching is also observed generally in various stream types (de Wit et al. 2016). Our results from analyses using RF (Figure 6) and PCA (Figure A1, Table A1 in Appendix) revealed that the main factor causing variations in nutrient and organic matter concentrations in stream water was past drainage, not local hydroclimate conditions. This shows that anthropogenic effects are the dominant factor affecting leaching in general, but leaching intensity will probably be highly sensitive to future changes in local climate and 


\section{Author's Accepted Manuscript}

300

301

302

303

304

305

306

307

308

309

310

311

312

313

314

315

316

317

318

319

320

321

322

323

324

especially fluctuations in soil moisture, temperature, and precipitation conditions. Fluctuations

in the watertable within peat layers at drained sites promotes oxidization of peat and increases pore water nutrient concentrations (Memberu et al. 2017, Munic et al. 2017), and thus increases the risk of leaching of dissolved nutrients to watercourses. In summary, the combined effect of changing climate (temperature, precipitation), increasing peat decomposition level due to drainage, and fluctuating watertables creates a high risk of nutrient leaching from drained peatland, which may explain the increasing loads from old drained peatlands reported by e.g. Nieminen et al. (2017).

\subsection{Variations in suspended solids and iron concentrations}

Suspended solids $\left(\mathrm{SS}_{1.2}, \mathrm{SS}_{0.4}\right)$ and $\mathrm{Fe}$ concentrations increased with percentage of drained peatland area in the catchment, indicating that drainage promotes erosion and transport from catchments. The proportion and variation in particulate organic matter (expressed as LOI) at drained sites was probably caused by erosion in the drainage network and/or of peat extraction surfaces, leading to an increase in organic suspended solids concentrations (Tuukkanen et al. 2014, 2016, Marttila and Kløve 2008). There is a higher risk of erosion in areas with old peat formations in particular, due to higher decomposition level in deeper peat layers (Svahnbäck 2007, Tuukkanen et al. 2014). Transport of $\mathrm{Fe}$ is also affected by the relative proportions of organic and inorganic fractions, as Fe is often transported attached to particles (Figure 4). The Fe concentrations were rather high at all sites, which may lead to increased flocculation together with humic acids and thus formation of organic particulate solids. The results from our PCA and RF analyses demonstrated that SS and Fe transport was associated more strongly with preceding local hydroclimate conditions than the percentage of drained peatland in the catchment area (Figure 6). In particular, higher preceding mean temperature resulted in higher SS and Fe concentrations (Figure 4), indicating that drier surface peat layers in ditches or 


\section{Author's Accepted Manuscript}

325

326

327

328

329

330

331

332

333

334

335

336

337

338

339

340

341

342

343

344

345

346

347

348

349

extraction activity (more activities during dry period) cause increased erosion and transport. Interestingly, stable water isotopes and silica analyses demonstrated that $\mathrm{SS}$ and $\mathrm{Fe}$ concentrations were linked to local groundwater or soil water sources (Figures 3 and 5). This suggests that some suspended solids originates from leaching of dissolved Fe from groundwater, which later flocculates particles in runoff waters and forms suspended solids.

Increasing Fe concentrations have been observed globally in boreal regions and have been attributed to changing soil redox conditions or sulfate deposition (Björnerås et al. 2017). Locally, however, peatland drainage is most probably the main reason for the higher Fe values. Higher deposition and transport of fine-grained organic matter in catchments dominated by drained peatland has been reported previously (Marttila and Kløve 2014, 2015, Tolkkinen et al. 2014, Laine and Heikkinen 2000), but these parameters are not usually monitored frequently in water quality sampling programs. Organic sediment is especially problematic for stream ecosystems and biochemical processes (Aspray et al. 2017), and can cause significant siltation or sliming of stream beds (Laine and Heikkinen 2000, Marttila and Kløve 2014). The LOI measurements in this study represent one of the first attempts to understand the quality of transported suspended solids in peatland-dominated catchments. Since inorganic and organic fractions can have different influences on water quality and ecology (Tank et al. 2010), it is essential to measure LOI as part of national monitoring. Another issue is selection of filter size and material for measurement of SS concentration in the laboratory. Based on our data, it appears that filters with $1.2 \mu \mathrm{m}$ pores do not trap all SS transported in humic waters, since the $0.4 \mu \mathrm{m}$ filters tested gave on average $8.8 \mathrm{mg}^{-1}$ higher values. This indicates that when using $1.2 \mu \mathrm{m}$ filters, laboratory analysis fails to detect part of the fine-grade suspended material, probably organic flocs or fine-grade mineral particles.

\subsection{Are current water protection measures sufficient in peat drainage areas?}




\section{Author's Accepted Manuscript}

350 Peatland use practices have a long history in the Nordic countries and peatland areas have been

351

352

353

354

355

356

357

358

359

360

361

362

363

364

365

366

367

368

369

370

371

372

373

374

managed intensively for forestry, agriculture, and peat extraction for decades (Paavilainen and

Päivänen 1995). This has resulted in economically valuable agricultural land and increasing

biomass production in drained forestry areas and peat extraction sites. Different methods have been actively developed to mitigate loading from anthropogenic actions for water protection purposes (e.g., Marttila and Klöve 2010, Heiderscheidt et al. 2013, Postila et al. 2014). However, recent studies have identified increasing nutrient leaching from old drained peatland areas (Nieminen et al. 2017). The main processes behind these elevated concentrations are suggested to be increasing decomposition of peat layers caused by artificial drainage, a relative rise in watertable as the peat layer compresses and thus increased leaching of elements from decomposed peat layers. Elevated concentrations of nutrients have also been reported in pore waters from old peatland forestry drainage areas (Memberu et al. 2017) and manipulated peatland (Munic et al. 2017). The results from the present study support these findings. At national scale and especially in the North Ostrobothnia region, where peatland comprise $40 \%$ of total area and 69\% are drained (Seväkivi and Tolvanen 2013), the threat of background leaching from old drainage areas increasing over time will hinder water improvement and require intensification of water protection measures. These recent findings also mean that we need to reconsider the previous understanding that drained peatland forestry areas reach natural background loads 5-10 years after drainage (Finér et al. 2010). Hence, actual loads from drained peatland and the efficiency of water protection methods, particularly in trapping dissolved nutrients, should be re-evaluated.

Our results also strongly suggest that despite decades of water protection efforts in boreal peatland areas drained for forestry and peat extraction, these areas are continuing to cause elevated concentrations and thus increasing loads to watercourses. In peatland-dominated catchments already under extensive drainage, this should be taken into account more carefully 


\section{Author's Accepted Manuscript}

375

376

377

378

379

380

381

382

383

384

385

386

387

388

389

390

391

392

393

394

395

396

397

398

399

when planning new or re-drainage operations and water protection measures. Current water protection measures are efficient in trapping particulate matter, but according to our results and the recent review by Nieminen et al. (2018b), efficient retention of dissolved nutrients is not achieved with current water protection efforts. Treatment wetlands may be an efficient measure for removing both dissolved and particulate nutrients, but they are challenging to establish, especially in areas with peatland forestry (Nieminen et al. 2018b). Moreover, although the majority of peat extraction sites in our dataset had treatment wetlands, elevated nutrient concentrations were still observed in study streams. In future, more attention should be paid to loads of dissolved nutrients from drained peatland in water quality management.

\section{Conclusions}

We analyzed 62 small catchments (area $0.1-44.8 \mathrm{~km}^{2}$ ) draining peatland-dominated landscapes under peatland forestry or peat extraction activities, or in pristine condition. Water and sediment sampling and water-stable isotopes analysis revealed elevated nutrient concentrations in headwaters from catchments with drained peatland. Higher dissolved nitrogen concentrations of $\mathrm{NH}_{4}-\mathrm{N}, \mathrm{NO}_{2+3}-\mathrm{N}$, and $\mathrm{PO}_{4}-\mathrm{P}$ in stream water resulted from drainage and leaching to streams from deeper peat soil layers. Particulate concentrations of nutrients, suspended solids, and LOI also showed elevated values in stream water in catchments with drained peatland. However, organic matter (TOC, DOC) and Fe concentrations in drained catchments were similar to those in pristine catchments. Past peatland drainage changed the quality of dissolved and particulate forms, especially $\mathrm{C} / \mathrm{N}$ ratio, and had a stronger effect on organic matter and nutrient losses than local hydroclimate conditions. In contrast, adjacent day temperature and precipitation were the most important variables explaining variations in concentrations of suspended solids and Fe. However, drainage increased the variation in concentrations of all transported elements, indicating that current water protection actions are not sufficient to trap all seasonal variations 


\section{Author's Accepted Manuscript}

400 in loads from peatland drainage areas. Thus, more effort and actions are needed for water

401 protection in peatland catchments.

402

403

\section{Acknowledgements}

404 We thank all those involved in the field sampling campaign for their generous help. This work 405 was part of the BioTar project funded by the European Regional Development Fund. Writing 406 and supported by Academy of Finland (AKVA grant no 263597) and BioWater-Nordic Center 407 of Excellence, funded by NordForsk. We thank the editor and anonymous reviewers for their

408 time and constructive comments, which helped improve the quality of this paper.

409

410

\section{References}

411

Aspray KL, Holden J, Legder ME, Mainstone CP, Brown LE. 2017. Organic sediment pulses

412 impact rivers across multiple levels of ecological organization. Ecohydrology 10(6), e1855.

413

414 Berggren M, del Giorgio P.A. 2015. Distinct patterns of microbial metabolism associated to 415 riverine dissolved organic carbon of different source and quality. Journal of Geophysical 416 Research: Biogeosciences, 120(6), 989-999.

417

418

Björnerås C, Weyhenmeyer GA, Evans D, Gessner MO, Grossart H-P, Kangur K, Kokorite I, 419 Kortelainen P, Laudon H, Lehtoranta J, Lottig N, Monteith DT, Nõges P, Nõges T, Oulehle F, 420 Riise G, Rusak JA, Räike A, Sire J, Sterling S, Kritzberg ES. 2017. Widespread increases in 421 iron concentration in European and North American freshwaters. Global Biogeochemical 422 Cycles, 31(10), 1488-1500

423 


\section{Author's Accepted Manuscript}

424

425 New York, pp 847-940

426

427

428

429

430

431

432

433

434

435

436

437

438

439

440

441

442

443

444 Finstad AG, Anderson T, Larsen S, Tominaga K, Blumentrath S, de Wit HA, Tommervik H, 445

446 447 Reports 6, 31944.

Cutler DR, Edwards TC, Beard KH, Cutler A, Hess KT, Gibson J, et al., 2007.

Random forests for classification in ecology. Ecology 88, 2783-2792.

De Wit HA, Valinia S, Weyhenmeyer GA, Futter M, Kortelainen P, Austnes K, Hessen DO, Räike A, Laudon H, Vuorenmaa J. 2016. Current Browning of Surface Waters Will Be Further Promoted by Wetter Climate. Environ. Sci. Technol. Lett. 3, 430-435.

Eskelinen R, Ronkanen A-K, Marttila H, Isokangas E, Kløve B. 2016. Effect of soil frost on drained peat soils on snowmelt runoff and surface water quality. Boreal Environment Research, 21, 556-570

Finér L, Mattsson T, Joensuu S, Koivusalo H, Lauren A, Makkonen T, Nieminen M, Sirkka T, Ahti E, Kortelainen P, Koskiaho J, Leinonen A, Nevalainen R, Piirainen S, Saarelainen J, Sarkkola S, Vuollekoski M. 2010. A method for calculating nitrogen, phosphorus and sediment load from forest catchments. Suomen Ympäristö, 10/2010. ISBN 978-952-11-37563. [abstract in English]

Hessen DO. From greening to browning: Catchment vegetation development and reduced Sdeposition promote organic carbon load on decadal time scales in Nordic lakes. Scientific 


\section{Author's Accepted Manuscript}

452

453

454

455

456

457

458

459

460

461

462

463

464

465

466

467

468

469

470

Haapalehto T, Kotiaho JS, Matilainen R, Tahvanainen T. 2014. The effects of long-term drainage and subsequent restoration on water table level and pore water chemistry in boreal peatlands. Journal of Hydrology 519,1493-1505.

Heikkinen K. 1990. Transport of organic and inorganic matter in river, brook and peat mining water in the drainage basin of the river Kiiminkijoki. Aqua Fennica, 20(2), 143-155.

Heiderscheidt E, Saukkoriipi JT, Ronkanen A-K, Klöve B. 2013. Optimisation of chemical purification conditions for direct application of solid metal salt coagulants: Treatment of peatland-derived diffuse runoff. Journal of Environmental Sciences 25(4), 659-669.

Huotari J, Nykänen H, Forsius M, Arvola L. 2013. Effect of catchment characteristics on aquatic carbon export from a boreal catchment and its importance in regional carbon cycling. Global Change Biology, 19(12), 3607-3620.

Isokangas E, Rossi PM, Ronkanen A-K, Marttila H, Rozanski K, Kløve B. 2017. Quantifying spatial groundwater dependence in peatlands through a distributed isotope mass balance approach. Water Resources Research, 53(3), 2524-2541.

Karjalainen S-M, Marttila H, Hellsten S. 2015. New methods to assess the impacts of peat land use on water bodies - Final report of BioTar project. Reports of the Finnish Environment Institute $11 / 2015,114 \mathrm{p}$. 
Author's Accepted Manuscript

471

472 Laine J, Vasander H. 1996. Ecology and vegetation gradients of peatlands. In: Vasander, H.

473 (Ed.) Peatlands in Finland. Finnish Peatland Society, Helsinki Finland. pp 10-19

474

475 Laine A, Heikkinen K. 2000. Peat mining increasing fine-grained organic matter on the riffle

476 beds of boreal streams. Archiv fur Hydrobiologie 148(1):9-24

477

478 Lepistö A, Futter MN, Kortelainen P. 2014. Almost 50 years of monitoring shows that

479 climate, not forestry, controls long-term organic carbon fluxes in a large boreal watershed.

480 Global Change Biology, 20(4), 1225-1237.

481

482 Marttila H \& Kløve B 2008. Erosion and delivery of deposited peat sediment, Water

483 Resources Research 44, W06406

484

485

Marttila H \& Kløve B 2010. Managing runoff, water quality and erosion in peatland forestry

486

by peak runoff control. Ecological engineering 36(7):900-911.

487

488

Marttila H, Kløve B. 2014. Storage, properties and seasonal variations in fine-grained bed

489

sediment within the main channel and headwaters of the River Sanginjoki, Finland.

490

Hydrological Processes 28(17), 4756-4765.

491

492 Marttila H, Kløve B. 2015. Spatial and temporal variation in particle size and particulate

493 organic matter content in suspended particulate matter from peatland-dominated catchments

494 in Finland. Hydrological Processes 29 (6), 1069-1079.

495 


\section{Author's Accepted Manuscript}

496

497

498

499

500

501

502

503

504

505

506

507

508

509

510

511

512 Montanarella L, Jones RJ, Hiederer R. 2006. The distribution of peatland in Europe, Mires 513 Peat, 1.

514

515 Munic TM, Khadka B, Xu B, Strack M. 2017. Mineral nitrogen and phosphorus pools affected

516 by water table lowering and warming in a boreal forested peatland. Hydrological processes, in 517 press.

518

Marttila H, Dudley B, Graham S, Srinivasan MS. 2018. Does transpiration from invasive

stream side willows dominate low flow conditions? An investigation using hydrometric and isotopic methods in a headwater catchment. Ecohydrology, 11(2), e1930.

Mattson T, Finér L, Kortelainen P, Sallantaus T. 2003. Brook water quality and background leaching from unmanaged forest catchments. Water, Air, and Soil Pollution, (147), 275-297.

Memberu MW, Marttila H, Tahvanainen T, Kotiaho JS, Hokkanen R, Klöve B, Ronkanen A$\mathrm{K}$. Changes in pore water quality after peatland restoration: Assessment of a large-scale, replicated Before-AfterControl-Impact study in Finland. Water Resources Research, 53(10), 8327-8343.

Meyer-Jacob C, Tolu J, Bigler C, Yang H, Bindler R. 2015. Early land use and centennial scale changes in lake-water organic carbon prior to contemporary monitoring. PNAS, 112(21), 6579-6584.

Peat, 1 .$$
\text { press. }
$$ 


\section{Author's Accepted Manuscript}

519 Nieminen M, Sallantaus T, Ukonmaanaho L, Nieminen TM, Sarkkola S. 2017. Nitrogen and

520 prhosphorus concentrations in dicharge from drained peatland forests are increasing. Science

521 of the Total Environment 609, 974-981.

522

523 Nieminen M, Palviainen M, Marttila H, Lauren A, Sarkkola S, Finer L. 2018a. A synthesis of

524 the impacts of ditch network maintenance on the quantity and quality of runoff from drained

525 boreal peatland forests. Published On-line Ambio

526

527 Nieminen M, Piirainen S, Sikström U, Sarkkola S, Löfgren S, Marttila H, Lauren A, Leena F. 528 2018b. Ditch network maintenance in boreal peatland forests - review and analysis of water 529 quality management options. Published on-line Ambio.

530

531 Paavilainen, E., Päivänen, J., 1995. Peatland forestry: ecology and principles. Ecological 532 Studies 111. Springer-Verlag, Berlin Heidelberg.

533 Prowse, T., A. et al. (2015), Arctic Freshwater Synthesis: Summary of key emerging issues. J 534 of Geophysical Research-Biogeosciences 120, 1887-1893.

535

536 Postila H, Saukkoriipi J, Heikkinen K, Karjalainen S-K, Kuoppala M, Marttila H, Kløve B. 537 2014. Can treatment wetlands be constructed on drained peatlands for efficient purification of 538 peat extraction runoff? Geoderma, 228-229, 33-34.

539

540 Rantakari M, Mattsson T, Kortelainen P, Piirainen S, Finér L, Ahtiainen M. 2010. Organic and 541 inorganic carbon concentrations and fluxes from managed and unmanaged boreal first-order 542 catchments. The Science of the Total Environment, 408(7), 1649-58. 


\section{Author's Accepted Manuscript}

544 Räike A, Kortelainen P, Mattsson T, Thomas DN. 2012. 36 year trends in dissolved organic

545 carbon export from Finnish rivers to the Baltic Sea. Sci. Tot. Environ. 435-436, 188-201.

546

547 Rääpysjärvi J, Hämäläinen H, Aroviita J. 2016. Macrophytes in boreal streams:

548 Characterizing and predicting native occurrence and abundance to assess human impact.

549 Ecological Indicators 64: 309-318.

550

551 Sarkkola S, Nieminen M, Koivusalo H, Laurén A, Kortelainen P, Mattsson T, Palviainen M,

552 Piirainen S, Starr M, Finér L. 2013. Iron concentrations are increasing in surface waters from

553 forested headwater catchments in eastern Finland. Sci Total Environ., 463-464, 683-690.

554

555 Seväkivi M-L, Tolvanen A. 2013. Katsaus soiden monimuotoisuuden tilaan Pohjois-

556 Pohjanmaalla. In: Soiden ekosysteemipalvelut ja maankäytön suunnittelu- tuloksia

557 soisimmasta Suomesta, edited by Tolvanen A. and Juutinen A. Metlan työraportteja 258, 558 pp.253.

559

560 Sponseller RY, Blackburn M, Nilsson B, Laudon H. 2017. Headwater Mires Constitute a

561 Major Source of Nitrogen (N) to Surface Waters in the Boreal Landscape. Ecosystems 1-14.

562

563 Svahnbäck L. 2007. Precipitation-induced runoff and leaching from milled peat mining mires

564 by peat types: a comparative method for estimating the loading of water bodies during peat

565 production. Doctoral Thesis. University of Helsinki, Faculty of Science, Department of

566 Geology.

567 


\section{Author's Accepted Manuscript}

568 Tank JL, Rosi-Marshall EJ, Griffiths NA, Entrekin S, Stephen ML. 2010. A review of

569 allochthonous organic matter dynamics and metabolism in streams. Journal of the North

570 American Benthological Society, 29(1), 118-146.

571

572 Tattari S, Koskiaho J, Kosunen M, Lepistö A, Liljama J, Puustinen M. 2017. Nutrient loads

573 from agricultural and forested areas in Finland from 1981 up to 2010-can the efficiency of

574 undertaken water protection measures seen? Environmental Monitoring and Assessment

$575189(3), 95$.

576

577 Tolkkinen, M., Marttila, H., Saukkoriipi, J., Martinmäki, K., Tammela, S., Tertsunen, J.,

578 Heikkinen, K., Tuohino, J., Ihme, R., Kløve B. pH-levels in intensively drained and peatland

579 dominated river basin: paleolimnological approach to detect impacts of past land use. 2014.

580 Ecological Engineering, 64, 367-376.

581

582 Tuukkanen T, Marttila H, Kløve B. 2014. Effect of soil properties on peat erosion and

583 suspended sediment delivery in peat extraction sites. Water Resources Research 50(4), 3523-

5843535.

585

586 Tuukkanen T, Stenberg L, Finér L, Marttila H, Piirainen S, Koivusalo H., Kløve B. 2016.

587 Erosion mechanisms and sediment sources in a peatland forest after ditch cleaning. Earth

588 Surface Processes and Landforms, 41(13), 1841-1853.

589

590 Vuorenmaa J, Forsius M, Mannio J. 2006. Increasing trends of total organic carbon

591 concentrations in small forest lakes in Finland from 1987 to 2003. Sci. Tot. Environ. 365, 47-

59265. 


\section{FIGURES}

595
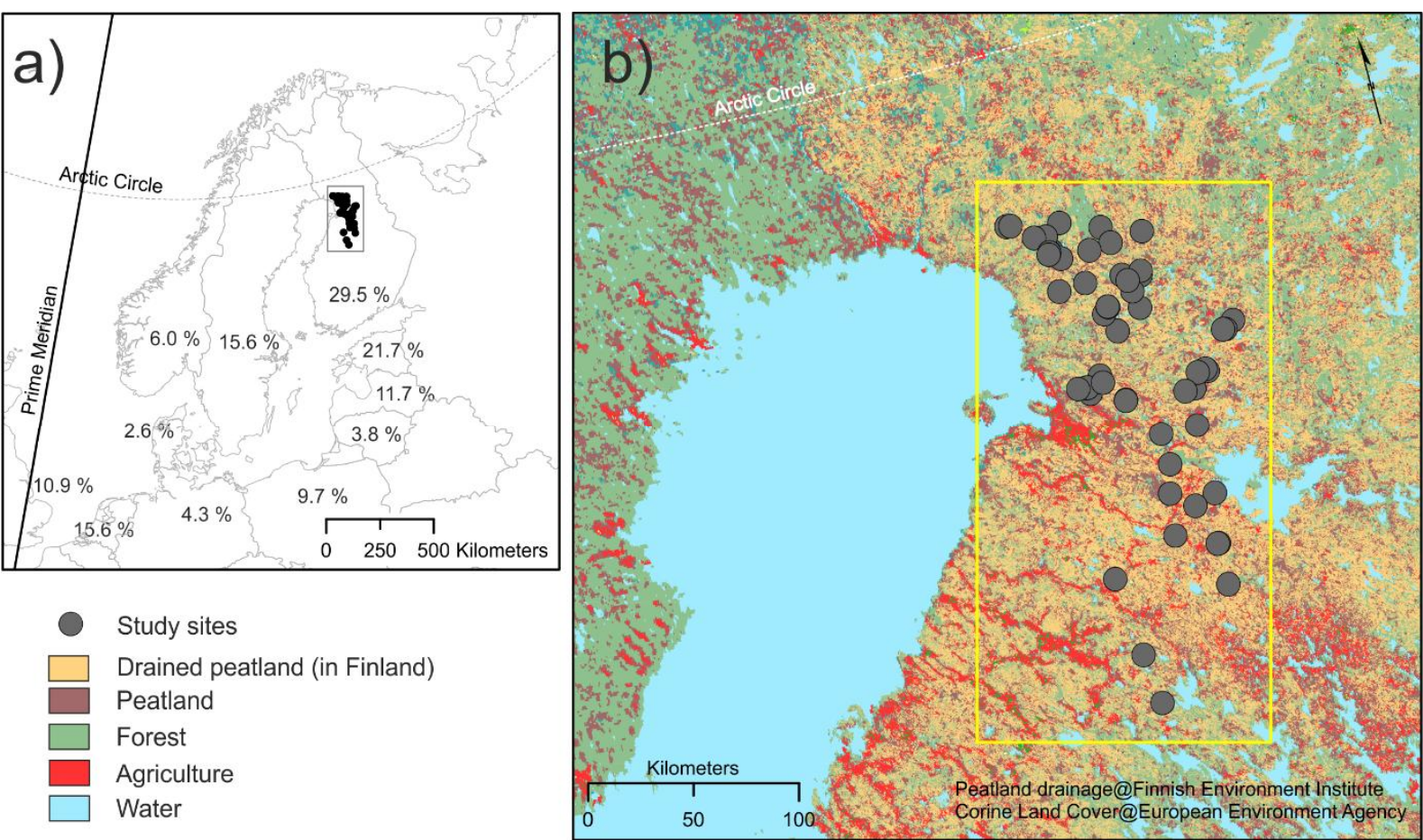

596

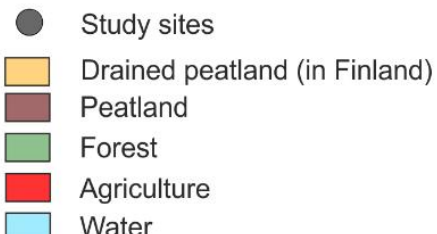

597 Figure 1. a) Location and distribution of study sites across in North Ostrobothnia, Finland, and

598 b) percentage of peat soil cover ( $>30 \mathrm{~cm}$ peat thickness) in Northern Europe (Montanarella et

599 al. 2006). 

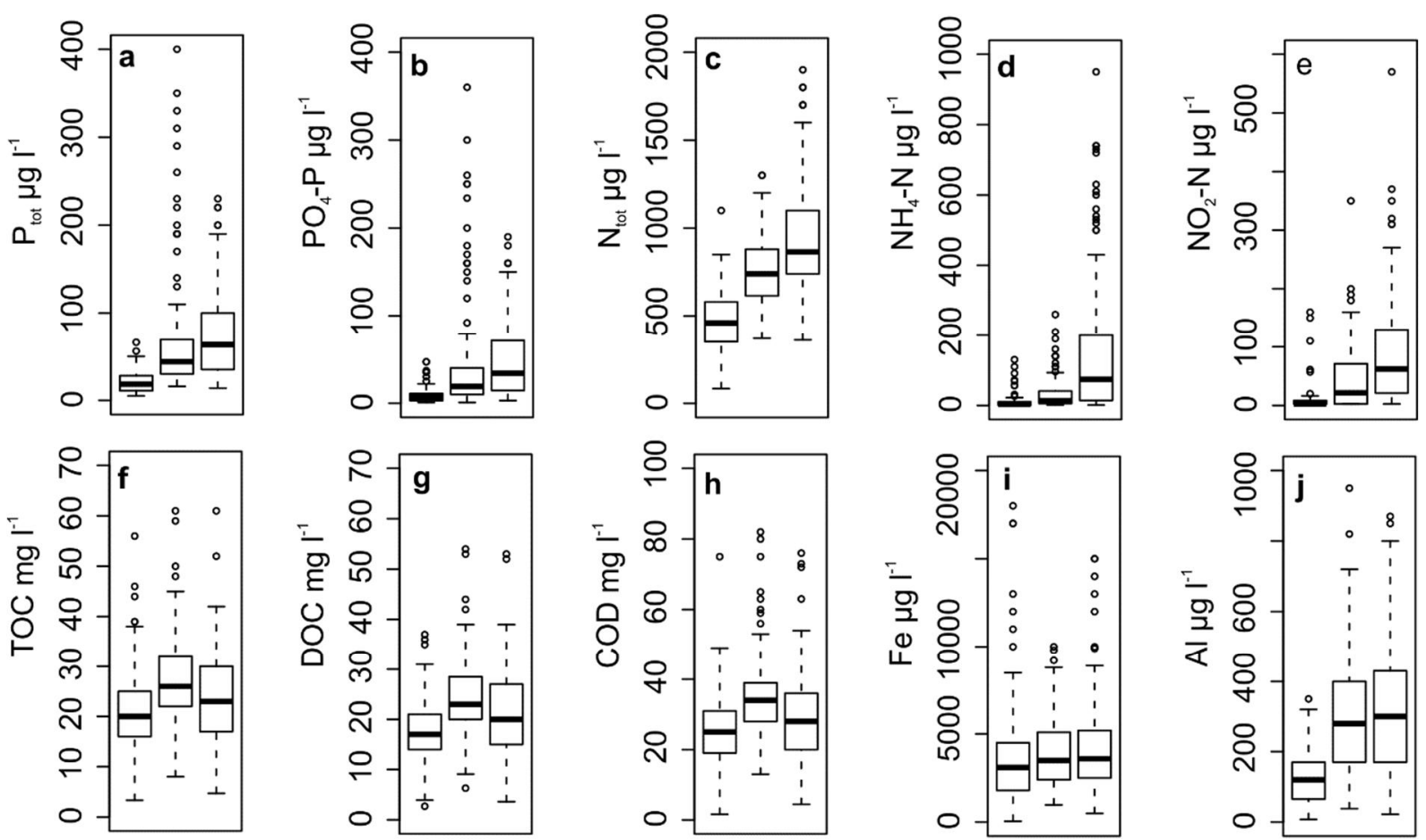

600
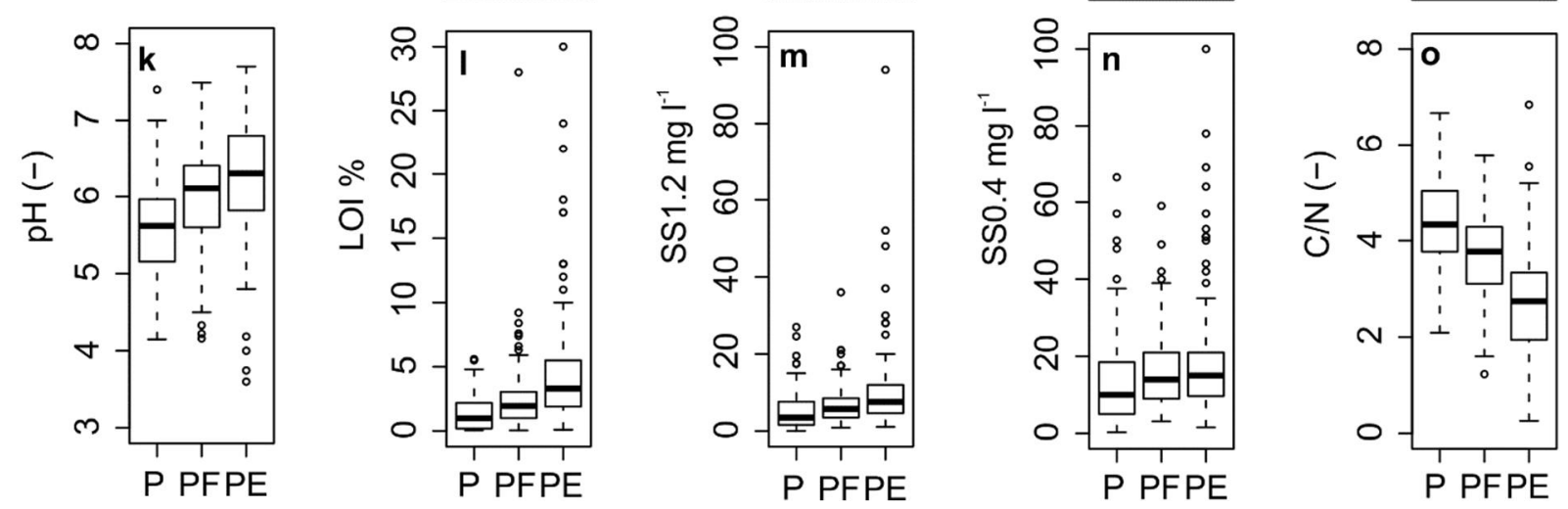

601 Figure 2. Variation in a) $\mathrm{P}_{\text {tot }}$, b) $\mathrm{PO}_{4}-\mathrm{P}$, c) $\mathrm{N}_{\text {tot }}$, d) $\mathrm{NH}_{4}-\mathrm{N}$, e) $\mathrm{NO}_{2+3}-\mathrm{N}$, f) TOC, g) DOC, h)

$602 \mathrm{COD}$, i) $\mathrm{Fe}$, j) $\mathrm{Al}, \mathrm{k}) \mathrm{pH}, \mathrm{l}) \mathrm{LOI}, \mathrm{m}) \mathrm{SS}_{1.2}$, and n) $\mathrm{SS}_{0.4}$ concentrations, and o) C/N ratio for

603 particulates in stream water, grouped based on samples from near pristine $(\mathrm{P})$, peatland

604 forestry (PF), and peat extraction (PE) sites. 


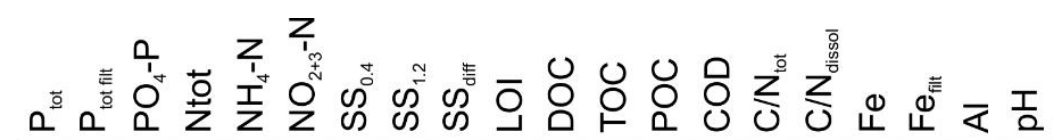

Same day $P$

7-days $P$

30-days $P$

Same day $T$

7-days $T$

30-days T

Water $T$

$\delta^{18} \mathrm{O}$

$\delta^{2} \mathrm{H}$

$\delta^{13} \mathrm{C}$

$\delta^{15} \mathrm{~N}$

$\square \square \quad \square \square \square$

$\mathrm{C} / \mathrm{N}$

$\mathrm{SiO}_{2}$

Undrained peatland (\%)
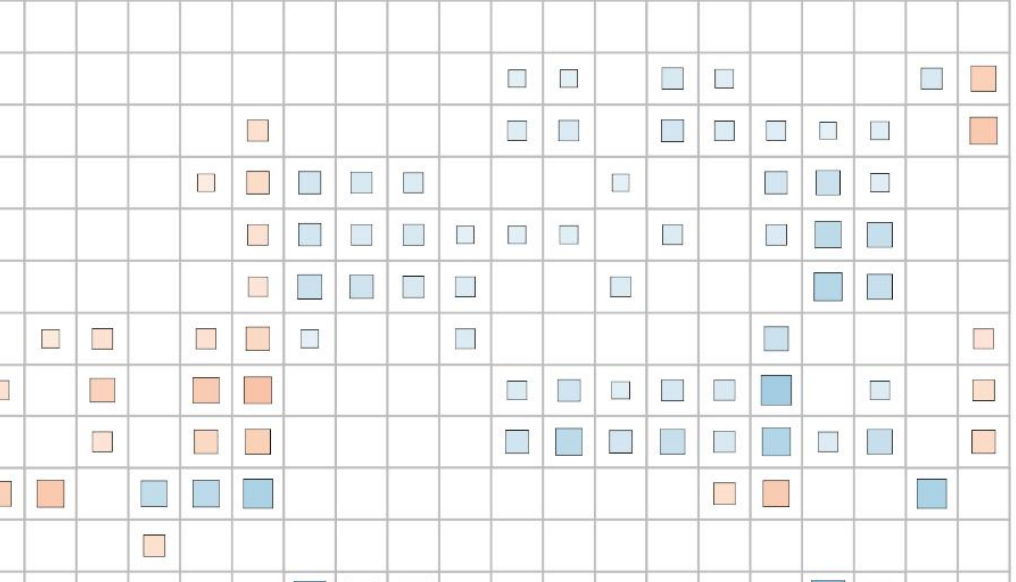

$P^{2}$

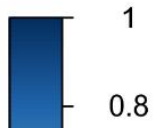

Drained peatland (\%)

Peat extraction (\%)

\begin{tabular}{|l|l|l|}
$(\%)$ & $\square$ & $\square$ \\
\hline$(\%)$ & $\square$ & \\
\hline ) & $\square$ & $\square$
\end{tabular}

$\square$

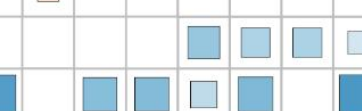

Other land use (\%)
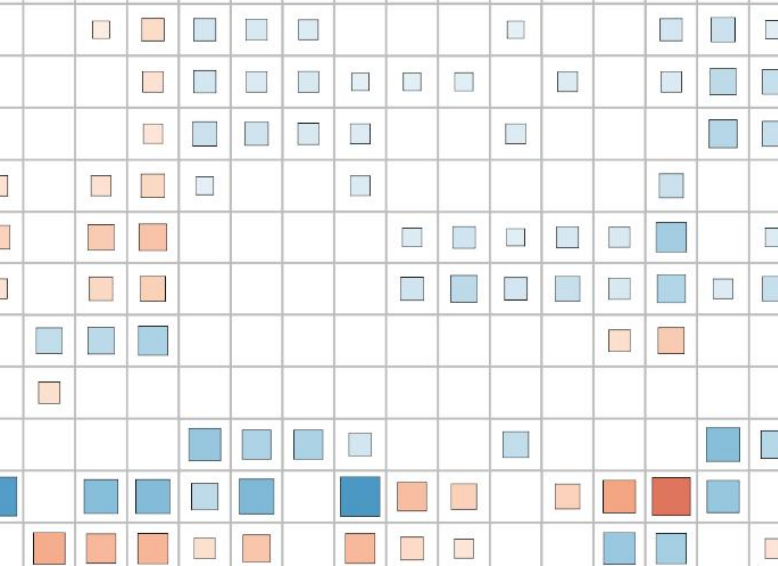

606 Figure 3. Correlation matrix (Pearson, significance level $\mathrm{p}<0.05$ ) of water quality parameters

607 and weather parameters, isotopes, and land use percentages in study catchments. $\mathrm{P}=$ 608 precipitation, $\mathrm{T}=$ air temperature.

609
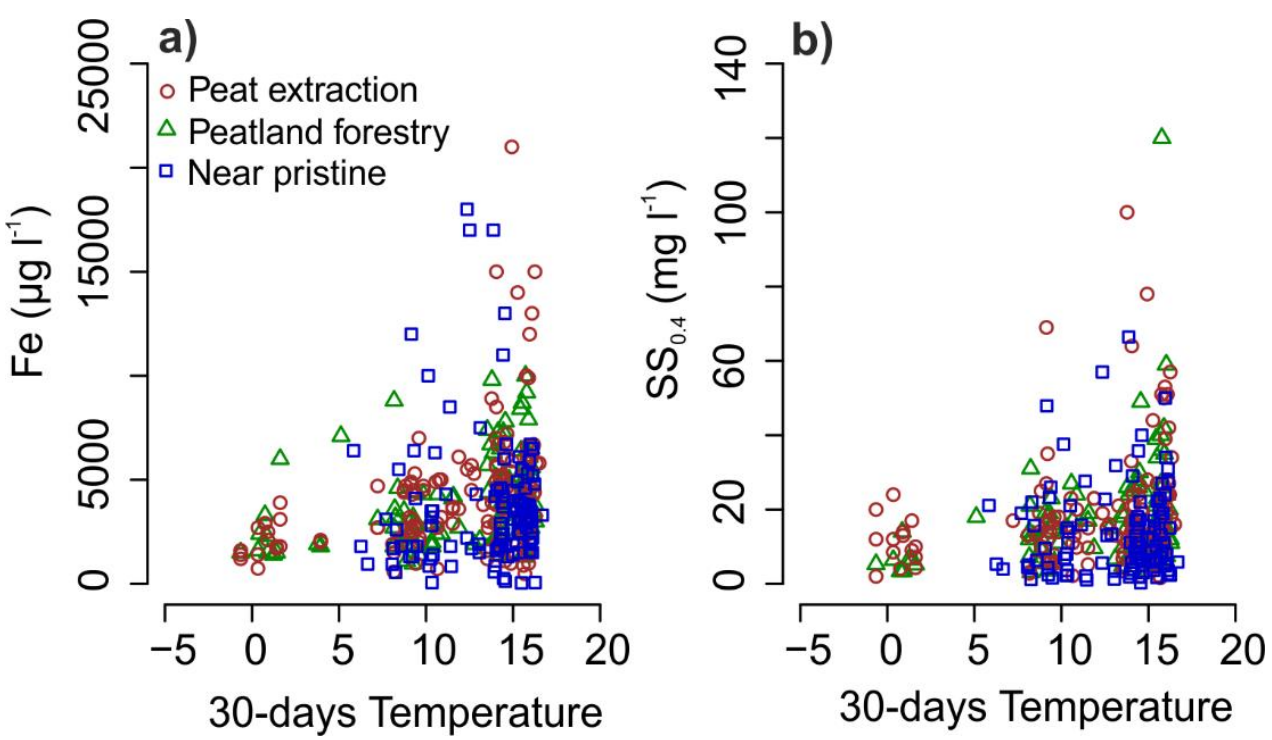

610

611 Figure 4. a) Iron (Fe) concentration and (b) suspended solids concentration with $0.4 \mu \mathrm{m}$ filter

612 (SS0.4) as a function of mean temperature in the 30-day period prior to sampling date. 

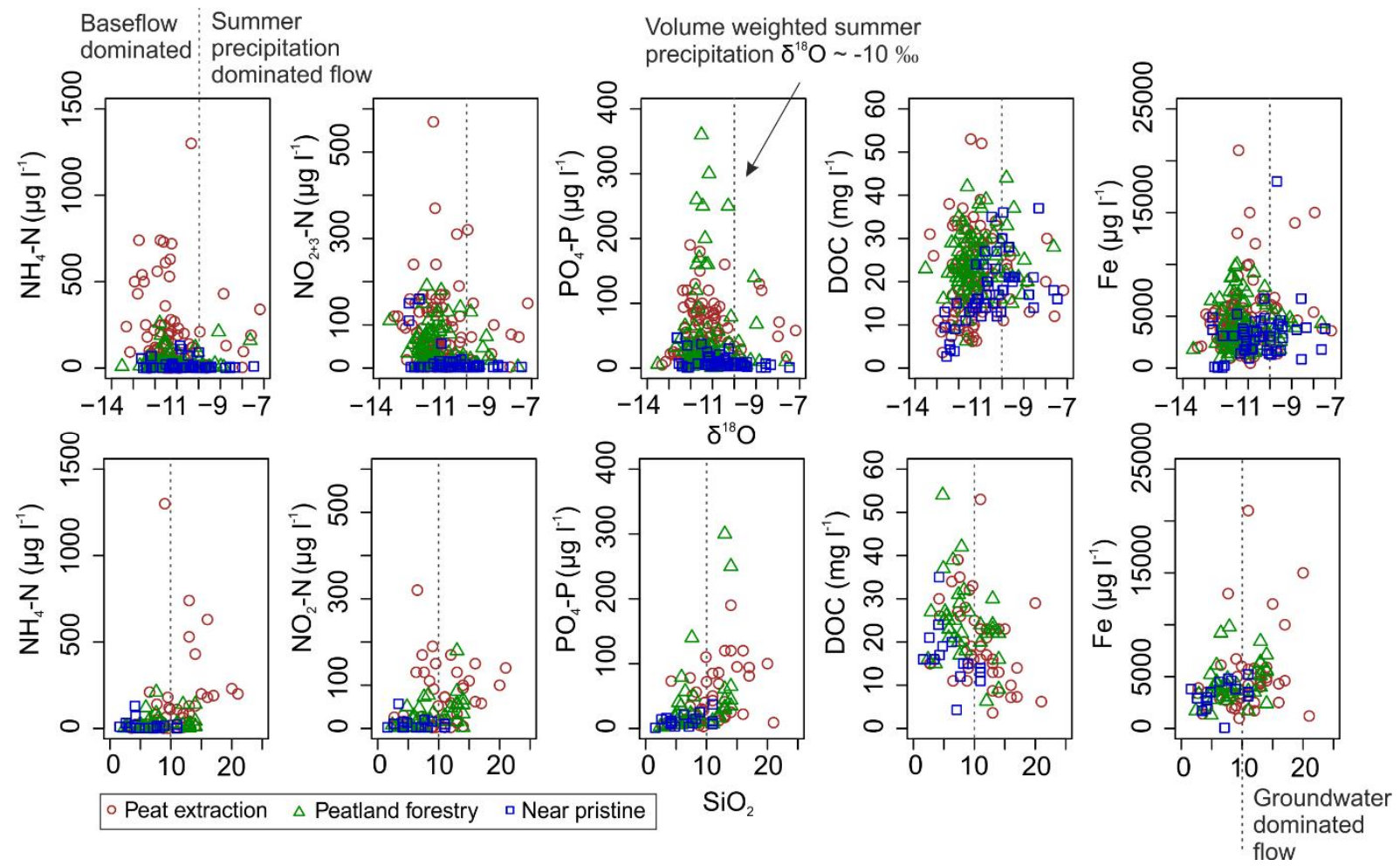

613 - Peat extraction $\triangle$ Peatland forestry $\quad$ Near pristine $\quad \mathrm{SiO}_{2}$

614 Figure 5. Stable oxygen-18 isotope $\left(\delta^{18} \mathrm{O}\right.$, upper diagrams) and silica $\left(\mathrm{SiO}_{2}\right.$, lower diagrams $)$

615 values in relation to ammonium $\left(\mathrm{N}-\mathrm{NH}_{4}\right)$, nitrate $\left(\mathrm{N}-\mathrm{NO}_{2}\right)$, phosphate $\left(\mathrm{P}-\mathrm{PO}_{4}\right)$, dissolved 616 organic carbon (DOC), and iron (Fe) concentrations. Gray line indicates volume-weighted summer precipitation $\left(\delta^{18} \mathrm{O} \sim-10 \%\right.$ in the study region).

618

a)

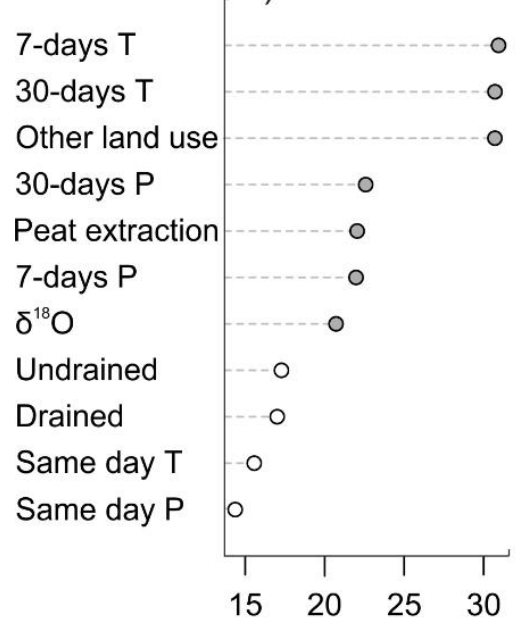

619 b)

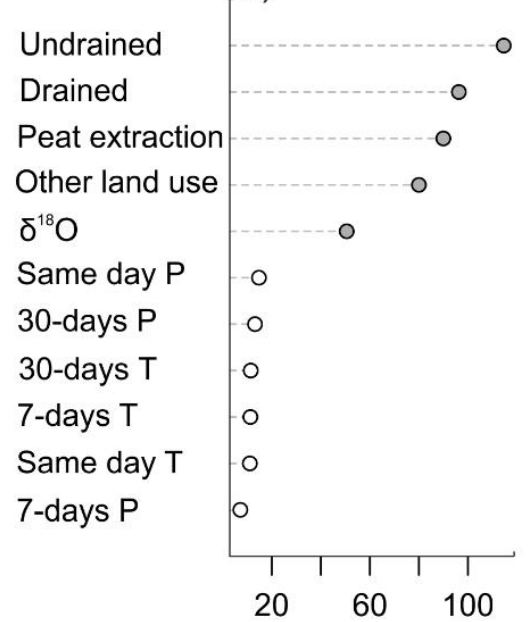

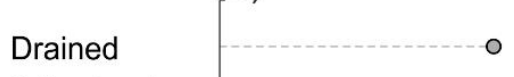

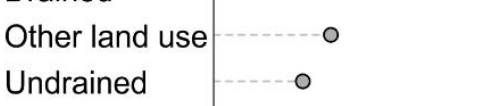

Peat extraction --. 0

7-days T $-\cdots$

$\delta^{18} \mathrm{O} \quad-\mathrm{O}$

Same day $T$ - $-\circ$

30-days P

7-days $P$

30-days T $\quad 0$

Same day $P$ o

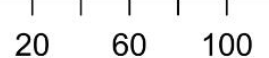

Mean decrease in accuracy

620 Figure 6. Random forest model results for variable importance of principal component analysis

621 (PCA) components (see Figure A1 in Appendix) for a) suspended solids, b) nutrients, and c) 


\section{Author's Accepted Manuscript}

622 carbon. Gray dots denote the variables selected for the final model. $\mathrm{P}=$ rainfall, $\mathrm{T}=$ atmospheric

623 temperature, drained $=$ drained peatland area, undrained $=$ undrained peatland area, other land

624 use $=$ area of other land use activities, peat extraction $=$ site including peat extraction area and

625 where $\delta^{18} \mathrm{O}$ is the stable isotope of oxygen.

626

627 
Author's Accepted Manuscript

628 TABLES

629

630 Table 1. Land use type, number of sites, and land use at the sites included in this study

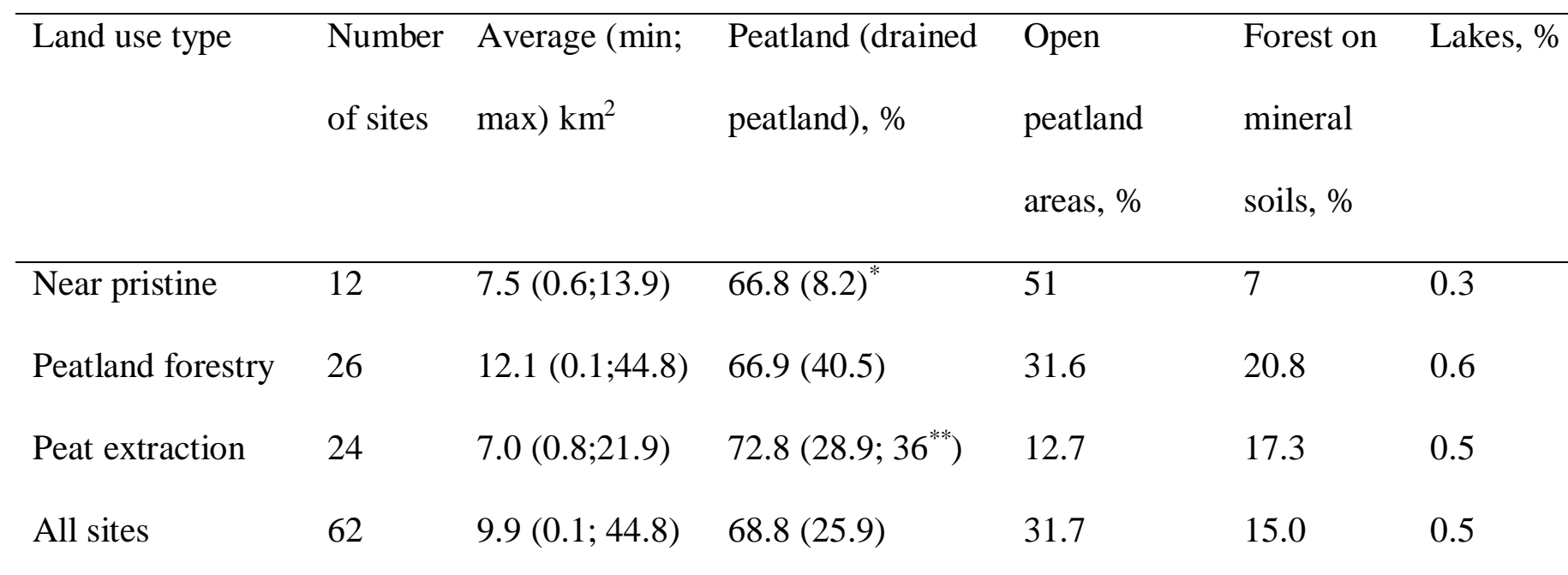

631 "Drainage systems older than 10 years. ${ }^{* *}$ Area of peat extraction operations.

632

633 


\section{Author's Accepted Manuscript}

634 Table 2. Summary of minimum, median, and maximum values of water quality parameters at sites with different land use types

$635(\mathrm{n}=$ number of samples in each dataset $)$.

\begin{tabular}{|c|c|c|c|c|c|c|c|c|c|c|c|c|c|c|c|c|c|c|}
\hline & $\underset{(\mu \mathrm{g} / \mathrm{l})}{\mathrm{P}_{\mathrm{tot}}}$ & $\begin{array}{l}\text { Dissolved } \\
\mathrm{P}_{\text {tot }}(\mu \mathrm{g} / \mathrm{l})\end{array}$ & $\begin{array}{l}\mathrm{PO}_{4}-\mathrm{P} \\
(\mu \mathrm{g} / \mathrm{l})\end{array}$ & $\begin{array}{c}\mathrm{N}_{\mathrm{tot}} \\
(\mu \mathrm{g} / \mathrm{l})\end{array}$ & $\begin{array}{c}\mathrm{NH}_{4}-\mathrm{N} \\
(\mu \mathrm{g} / \mathrm{l})\end{array}$ & $\begin{array}{c}\mathrm{NO}_{2+3}-\mathrm{N} \\
(\mu \mathrm{g} / \mathrm{l})\end{array}$ & $\begin{array}{l}\mathrm{TOC} \\
(\mathrm{mg} / \mathrm{l})\end{array}$ & $\begin{array}{l}\mathrm{DOC} \\
(\mathrm{mg} / \mathrm{l})\end{array}$ & $\begin{array}{c}\mathrm{COD}_{\mathrm{Mn}} \\
(\mathrm{mg} / \mathrm{l})\end{array}$ & $\begin{array}{c}\mathrm{Fe} \\
(\mu \mathrm{g} / \mathrm{l})\end{array}$ & $\begin{array}{l}\text { Dissolved } \\
\mathrm{Fe}(\mu \mathrm{g} / \mathrm{l})\end{array}$ & $\begin{array}{c}\mathrm{Al} \\
(\mu \mathrm{g} / \mathrm{l})\end{array}$ & $\mathrm{pH}$ & $\begin{array}{c}\mathrm{EC} \\
(\mathrm{mS} / \mathrm{m})\end{array}$ & $\begin{array}{c}\mathrm{SS}_{0.4} \\
(\mathrm{mg} / \mathrm{l})\end{array}$ & $\begin{array}{c}\mathrm{SS}_{1.2} \\
(\mathrm{mg} / \mathrm{l})\end{array}$ & $\begin{array}{l}\text { LOI } \\
(\%)\end{array}$ & $\begin{array}{c}\mathrm{C} / \mathrm{N} \\
\text { particulate } \\
(-)\end{array}$ \\
\hline \multicolumn{19}{|c|}{$\begin{array}{l}\text { Peat extraction } \\
\mathrm{n}=136\end{array}$} \\
\hline Min & 16 & 12 & 3 & 516 & 1 & 3 & 13.0 & 9.3 & 14 & 730 & 515 & 37 & 5.4 & 5.41 & 3.50 & 1.85 & 27.88 & 2.92 \\
\hline Mdn & 64 & 23 & 35 & 855 & 79 & 46 & 21.7 & 19.0 & 26 & 4100 & 1975 & 280 & 5.2 & 6.25 & 16.50 & 7.75 & 57.69 & 12.85 \\
\hline Max & 960 & 63 & 900 & 8000 & 4100 & 190 & 38.0 & 33.5 & 59 & |1375 & 5900 & 665 & 7.1 & 7.11 & 260.00 & 220.00 & 80.69 & 25.43 \\
\hline \multicolumn{19}{|c|}{$\begin{array}{l}\text { Peatland forestry } \\
n=131\end{array}$} \\
\hline Min & 19 & 12 & 3 & 510 & 2 & 3 & 11.7 & 10.1 & 15 & 1400 & 1237 & 47 & 4.4 & 2.11 & 3.60 & 2.40 & 51.31 & 8.45 \\
\hline Mdn & 43 & 22 & 19 & 712 & 13 & 13 & 26.0 & 24.0 & 33 & 3800 & 2050 & 295 & 5.9 & 3.40 & 15.00 & 7.10 & 67.61 & 14.18 \\
\hline $\operatorname{Max}$ & 257 & 122 & 219 & 1020 & 159 & 110 & 49.0 & 41.0 & 65 & 8250 & 5850 & 770 & 5.9 & 8.51 & 33.03 & 14.00 & 97.92 & 20.89 \\
\hline \multicolumn{19}{|c|}{$\begin{array}{l}\text { Near pristine } \\
\mathrm{n}=113\end{array}$} \\
\hline Min & 8 & 7 & 1 & 130 & 1 & 3 & 5.0 & 4.9 & 7.3 & 50.50 & 56 & 16 & 4.8 & 1.14 & 2.05 & 0.25 & 42.11 & 8.22 \\
\hline Mdn & 18 & 12 & 6 & 485 & 3 & 3 & 18.5 & 15.6 & 25 & 2900 & 1750 & 124 & 5.6 & 2.16 & 10.63 & 4.02 & 72.78 & 15.88 \\
\hline $\operatorname{Max}$ & 49 & 24 & 41 & 710 & 91 & 130 & 29.0 & 27.0 & 37 & 6109 & 3860 & 218 & 5.5 & 3.24 & 25.50 & 10.45 & 98.15 & 28.79 \\
\hline
\end{tabular}


638
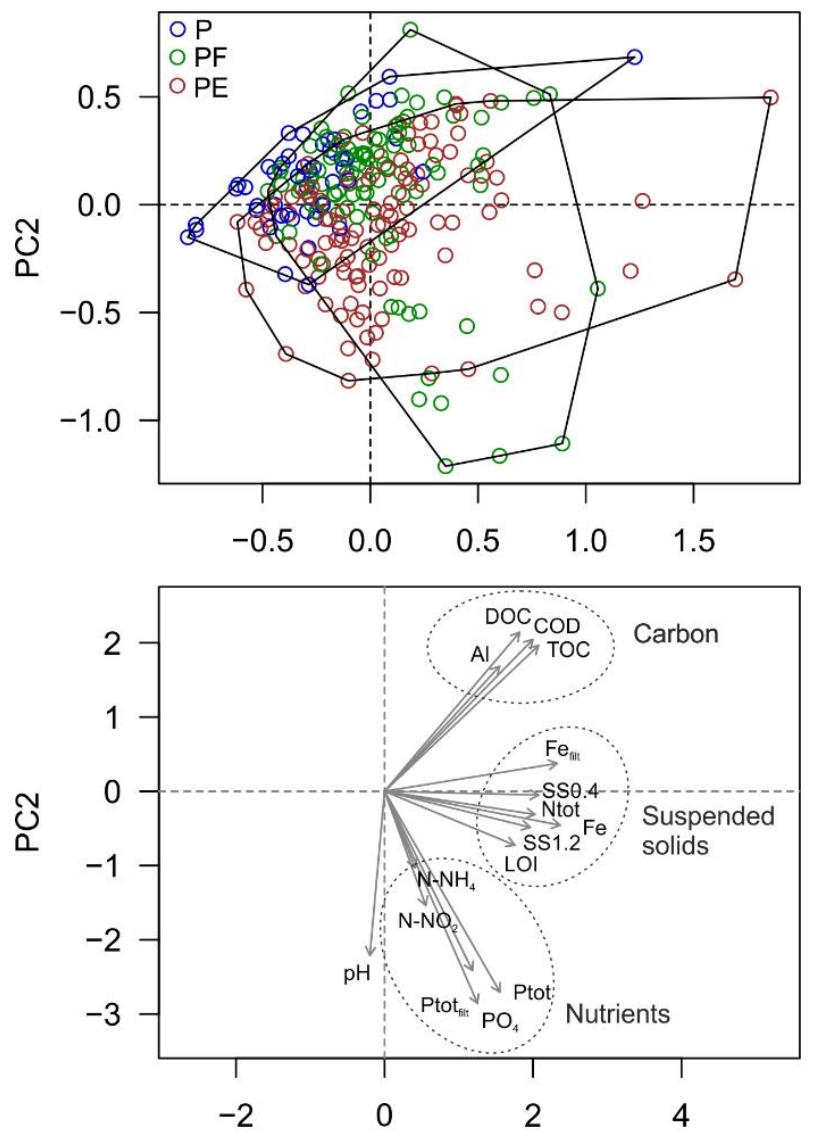

639 PC1

640 Figure A1. Principal component analysis (PCA) of water chemistry for different study groups

641 (pristine $\mathrm{P}$, peatland forestry PF, peat extraction PE). Vector length indicates the explanatory 642 power of the corresponding variable.

643

644

645

646

647

648 


\section{Author's Accepted Manuscript}

649 Table A1. Summary of principal component analysis (PCA) on water quality data. The

650 highest loads for each component are shown in bold.

\begin{tabular}{|c|c|c|c|c|}
\hline & PC1 & $\mathrm{PC} 2$ & PC3 & PC4 \\
\hline Eigenvalue & 5.49 & 3.10 & 2.28 & 1.64 \\
\hline$\%$ Explained & 34 & 19 & 14 & 10 \\
\hline Cumulative $\%$ explained & 34 & 53 & 70 & 80 \\
\hline $\mathrm{Al}$ & 1.067 & 0.872 & -0.286 & 0.241 \\
\hline TOC & 1.429 & 1.017 & 0.805 & 0.127 \\
\hline DOC & 1.254 & 1.109 & 0.902 & 0.105 \\
\hline COD & 1.377 & 1.058 & 0.793 & 0.045 \\
\hline SS1.2 & 1.353 & -0.252 & -0.990 & -0.791 \\
\hline SS0.4 & 1.429 & -0.026 & -0.819 & -0.747 \\
\hline $\mathrm{Fe}$ & 1.632 & -0.236 & -0.429 & -0.112 \\
\hline $\mathrm{Fe}_{\text {filt }}$ & 1.602 & 0.194 & -0.088 & 0.150 \\
\hline LOI & 1.210 & -0.376 & -0.984 & -0.772 \\
\hline Ntot & 1.396 & -0.162 & -0.408 & 1.101 \\
\hline Ptot & 1.071 & -1.401 & 0.784 & -0.068 \\
\hline Ptot $_{\text {filt }}$ & 0.816 & -1.251 & 1.119 & 0.045 \\
\hline $\mathrm{P}-\mathrm{PO}_{4}$ & 0.864 & -1.479 & 0.870 & -0.030 \\
\hline $\mathrm{N}-\mathrm{NH}_{4}$ & 0.284 & -0.533 & -1.091 & 1.251 \\
\hline $\mathrm{N}-\mathrm{NO}_{2}$ & 0.380 & -0.796 & -0.312 & 1.229 \\
\hline $\mathrm{pH}$ & -0.136 & -1.145 & 0.215 & -0.586 \\
\hline
\end{tabular}

651

652

653 